SAKAI SAMBAYAN — Jurnal Pengabdian kepada Masyarakat

\title{
OPTIMALISASI RUMAH BELAJAR DI PEKON SUKAMARGA KECAMATAN SUOH KABUPATEN LAMPUNG BARAT
}

\author{
Erlina Rufaidah ${ }^{1 *}$, Nurdin ${ }^{2}$ \\ Jurusan Pendidikan Ilmu Pengetahuan Sosial Universitas Lampung, Bandar Lampung \\ Jl. Prof. Sumantri Brojonegoro No.1 Bandar Lampung 35145 \\ Penulis Korespodensi : erlinarufaidah1985@gmail.com
}

\begin{abstract}
Abstrak
Rendahnya tingkat pembelajaran anak disebabkan karena minimnya informasi pembelajaran serta waktu belajar yang terbatas hanya di jam sekolah dan paradigma masyarakat tentang pentingnya dunia pendidikan bagi masa depan anak masih tergolong rendah. Tujuan pengabdian masyarakat ini adalah untuk memberi semangat bagi anak-anak untuk lebih giat belajar lagi serta menambah pemahaman serta memberikan wawasan tambahan pelajaran sekolah bagi peserta didik. Pengabdian masyarakat ini menerapkan model pelatihan dengan Multilevel Training. Dengan model pelatihan tersebut, diharapkan dapat meningkatkan pemahaman masyarakat terhadap Rumah Belajar sebagai salah satu Pusat Sumber Belajar bagi anak-anak. Secara keseluruhan dengan adanya Rumah Belajar dan aplikasi Manajemen Pelatihan dapat menjadi wahana pengembangan dan peningkatan kompetensi peserta didik. Hasil yang diharapkan dari pengabdian masyarakat ini ialah Rumah belajar diciptakan untuk bisa memberi semangat bagi masyarakat dan anak-anak untuk lebih giat belajar lagi. Anak-anak juga akan merasa nyaman dalam belajar karena mereka dapat belajar dengan model PAIKEM. Konsep pembelajaran tidak hanya difokuskan pada pencapaian materi belajar namun aplikasi setiap materi pelajaran dalam dunia nyata sehingga pada jangka panjang akan menimbulkan budaya belajar yang relevan.
\end{abstract}

Kata Kunci: Optimalisasi, pekon sukamarga, rumah belajar

\section{Pendahuluan}

Perkembangan dunia pendidikan yang seiring dengan berkembangnya Teknologi Informasi dan Komunikasi (TIK) menciptakan tantangan-tantangan baru dalam proses belajar mengajar. Permasalahan yang makin kompleks menuntut kesiapan dunia pendidikan untuk mengantisipasinya. Informasi dan pengetahuan yang semakin beragam dan mudah penyebarannya menuntut guru dan siswa untuk dapat terus mengembangkan kopetensi guna dapat turut andil dalam kemajuan bidang informasi pendidikan. Informasi dan pengetahuan ada yang bernilai positif ada juga yang negatif, oleh karena itu filter dari guru sangat diperlukan. Pada konsep dasarnya perkembangan informasi dan pengetahuan yang beragam sangat membantu dalam proses belajar mengajar dengan menggunaakan teknologi yang modern.

Pekon Sukamarga merupakan salah satu Desa (Pekon) yang ada di Kecamatan Suoh
Kabupaten Lampung Barat. Pekon sukamarga ini tepatnya berada di tengah-tengah areal Kawasan Taman Nasional Bukit Barisan Selatan (TNBBS). Daerah Suoh merupakan daerah yang hingga saat ini belum terfasilitasi listrik oleh PLN, sehingga sebagian masyarakat ada yang menggunakan kincir air ataupun genset (generator) untuk penerangan. Akses jalan di daerah Suoh juga masih dalam pembangunan, dimana masih banyak lintasan sungai kecil yang belum memiliki jebatan untuk menghubungkan jalan, sehingga kendaraan masyarakat Suoh harus sering melintasi sungai kecil untuk menuju tujuannya.

Minimnya teknologi informasi yang ada dirata-rata sekolah di Kabupaten Lampung Barat mengakibatkan kurangnya informasi bagi para siswa dalam memperoleh bahan pelajaran diluar waktu sekolah, selain itu guru sebagai fasilitator pendidikan tidak dapat berbuat banyak dikarenakan minimnya informasi yang didapat siswa sehingga proses belajar menjadi kurang efektif dan efisien. 
Kegiatan pembelajaran pada rumah belajar menitik beratkan pada pemahaman suatu konsep belajar secara mendasar untuk memicu adanya kreatifitas, inovasi dan fleksibilitas dalam kegiatan belajar. Produktifitas menjadi kunci dari tercapainya tujuan diciptakanya rumah belajar. Konsep produktifitas tercapai apabila setiap elemen yang dibutuhkan dalam pembelajaran dapat terpenuhi. Perekrutan sumber daya manusia yang kompeten dalam memberikan pengejaran serta kelengkapan media belajar menjadi pendorong tercapainya tujuan dari rumah pembelajaran. Fasilitas pembelajaran seperti runag baca, komputer, papan tulis dan perlengkapan lainnya perlu diperhatikan dalam pengembangan rumah belajar. Konsep Rumah Belajar yang menerapkan prinsip belajar aktif melalui tiga cara yaitu dengan kegiatan melihat, mendengar, dan Melakukan baik secara individu maupun kelompok dengan bimbingan pendidik (guru atau Senior) diharapkan dapat meminimalisir permasalahan pendidikan pada saat ini. Rumah Belajar merupakan suatu wadah perkumpulan siswa diluar waktu sekolah dimana memanfaatkan waktu bermain untuk belajar secara menarik dan menyenangkan.

\section{Bahan dan Metode}

Program Pengabdian yang dihadirkan berfokus pada peningkatan mutu pendidikan formal dengan mendorong pendidikan non formal melalui rumah belajar sebagai fasilitator pembelajaran diluar sekolah. Pengumpulan data mengenai kebutuhan data yang dilakukan menunjukan ketimpangan pendidikan diwilayah pedesaan. Problem tenaga pendidik dan peserta didik yang utama adalah kurang informasi pendidikan serta waktu belajar disekolah sanagt sempit, sedangkan tidak ada lembaga pendidikan diluar sekolah yang dapat memberikan akses pembelajaran non formal. Metode yang digunakan dalam program pengabdian ini adalah Sosialisasi dan Training. Teknik pengumpulan data menggunakan teknik observasi. Program pengabdian ini memiliki beberapa tahapan kerja mulai dari obsevasi masalah dilokasi, menentukan jenis program yang akan ditawarkan menjadi solusi sampai pada pelaksanaan program hingga evaluasi dan pembuatan laporan pelaksanaan program rumah belajar.

\section{Hasil dan Pembahasan}

Hasil dari pelaksanaan program rumah belajar memberikan pengaruh positif bagi peserta didik dalam bidang pendidikan. Rumah belajar didesaign senyaman mungkin bagi peserta didik tanpa adanya struktural kerja dimana guru dan murid seperti keluarga sehingga peserta didik dapat lebih mudah beradaptasi dan menceritakan kelemahan dalam pembelajaran. Pelatihan kepada pendidik tentang media dan model pembelajaran serta inovasi yang dapat dilakukan akan memudahkan pendidik dalam mentranformasikan ilmunya kepada peserta didik. Pada hakekatnya pendidikan tidak hanya sebatas mengajarkan materi pelajaran kepada peserta didik namun lebih dari itu, pendidik juga berperan dalam peningkatan kepedulian peserta didik (sosialisasi), budi pekerti, nasionalisme dan motivasi untuk dapat bercita-cita.

Kegiatan Rumah belajar disesuiakan dengan kebutuhan peserta didik pada masa sekarang dan masa mendatang. Penjadwalan kegiatan mengacu pada kebutuhan pemenuhan jam belajar sekolah yang relatif kurang pada mata pelajaran tertentu. Pada perkembanganya program pembelajaran dapat disesuikan kembali dengan maksud agar peserta didik juga memahami pelajaran lainnya. Kegiatan rumah belajar pada awalnya dikuti sebanyak 20 anak Sekolah Dasar (SD) dan Sekolah Menengah Pertama dan didampingi tenaga pendidik sebanyak 2 orang. Pada bulan selanjutnya perkembangan meningkat terus-menerus sehingga peserta didik bertambah lebih dari 30 anak. Tenaga pendidik yang mengajar yaitu Bapak. Muhaimin, S.Pd. dan Ibu Tri Sulastuti, S.Pd. yang juga merupakan guru SMP di Kecamatan Suoh.

Kegiatan rumah belajar yang mengambil waktu sore yang tidak menggangu waktu belajar sekolah sekaligus kegiatan ini pada dasarnya adalah membantu pemenuhan jam pelajran yang kurang disekolah. Peserta didik yang ikut serta dalam program ini dapat belajar pada lintas ilmu yang ada dengan media atau model yang menyenangkan. Pada kegiatan evaluasi tengah program Tim Rumah Belajar sengaja melakukan wawanca kepada beberapa peserta didik, pendidik dan wali murid sebagai sampel dalam pengabdian ini. Kegiatan wawanca dilakukan secara bertahap dengan materi pokok adalah mengukur tingkat minat dan pengaruh rumah belajar terhadap peningkatan budaya belajar. Hasil dari wawanca tersebut menunjukan bahwa sebagian besar 
masyarakat, pendidik dan peserta didik sangat menyetujui adanya program rumah belajar. Pada perhitungan sederhana lebih dari $70 \%$ pihak menyetujui program rumah belajar dan berharap program ini dapat dilaksanakan secara berkelanjutan dengan adanya kontrol, arahan serta evaluasi program sedang berjalan. Sebagian kecil yang menolak program berorientasi bahwa waktu bagi pendidikan anak sebatas pada keaktifan dalam kegiatan sekolah dan waktu sore hari digunakan untuk membantu orang tua bertani. Kondisi demikian sangat wajar mengingat masyrakat daerah suoh masih belum lama memiliki keterbukaan dalam dunia pendidikan.

Kendala yang dihadapi dalam melaksanakan program rumah belajar merupakan suatu tantangan nyata dunia pendidikan di masyarakat yang belum merasakan manfaat pendidikan. Pada tahap awal masyarakat cenderung kurang percaya dengan adanya program rumah belajar dikarenakan mengganggu jadwal anak untuk membantu orang tua bertani. Hasil musyawarah dengan Tim rumah Belajar akhirnya mengadakan perkumpulan untuk melakukan sosialisai program secara langsung kepada masyarakat yang di bantu oleh aparatur pemerintahan setempat.

Kegiatan rumah belajar menjadi sangat penting bagi terselenggranya pendidikan yang optimal dalam upaya meningkatkan kualitas sumber daya manusia dimasa mendatang. Program rumah belajar diharapkan mampu menaungi kekurangan jam belajar disekolah dan memperkenalkan pendidikan yang berbasis PAIKEM. Rumah belajar merupakan wadah pendidikan non formal yang dapat dijadikan wadah diskusi, kreasi, inovasi dan kegiatan kreatif lainnya. Pada tingkatakan tertinggi program rumah belajar diharapkan mampu mendukung program percepatan pembangunan nasional terutama bidang peningkatan kualitas SDM dari sejak usia dini.

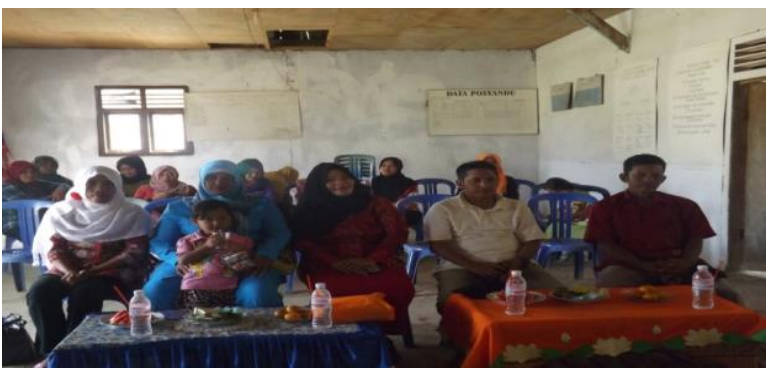

Gambar 1. Sosialisasi rencana pelaksanaan program rumah belajar kepada masyarakat.

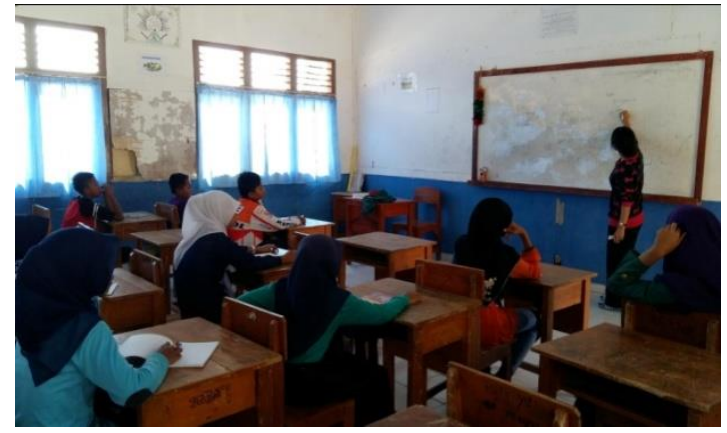

Gambar 2. Pelaksanaan kegiatan rumah belajar.

\section{Kesimpulan}

Kesimpulan dari pelaksanaan program rumah belajar adalah Program rumah belajar seyogyanya mampu mengakomodir kebutuhan peserta didik dalam meningkatkan kuantitas dan kualitas waktu belajar diluar waktu sekolah dengan menggunakan model dan media yang berbasis PAIKEM. Rumah belajar berupaya menjadi langkah awal peningkatan kualitas pendidikan didaerah suoh dengan mengadakan pembelajaran tambahan diluar waktu sekolah. Potensi suatu daerah yang tinggi seharusnya disejajarkan dengan membaiknya kualitas SDM didaerah tersebut melalui jalur pendidikan sehingga pada masa mendatang potensi daerah dapat dikembangkan dan dikelola oleh putra/i daerah yang bertujuan untuk meningkatkan kesejahtraan masyarakat.

\section{Daftar Pustaka}

Mulyadi, seto.2007. Home Schooling keluarga kakSeto. Bandung : Kaifa.

Franz, kurt. 1983. Membina minat baca. Bandung : CV Remaja Karya.

Schunk, Dale H., 2012, Learning Theories, an Perspective $6^{\text {th }}$ editions, Boston, Pearson Education, Inc.

Woolfolk, Anita, 2004, Educational Psychology, 9th editions, Boston, Pearson Education, Inc. 